Document downloaded from:

http://hdl.handle.net/10251/115880

This paper must be cited as:

Asensio-Grau, A.; Calvo-Lerma, J.; Heredia Gutiérrez, AB.; Andrés Grau, AM. (2018). Fat digestibility in meat products: influence of food structure and gastrointestinal conditions. International Journal of Food Sciences and Nutrition. 8.

doi:10.1080/09637486.2018.1542665

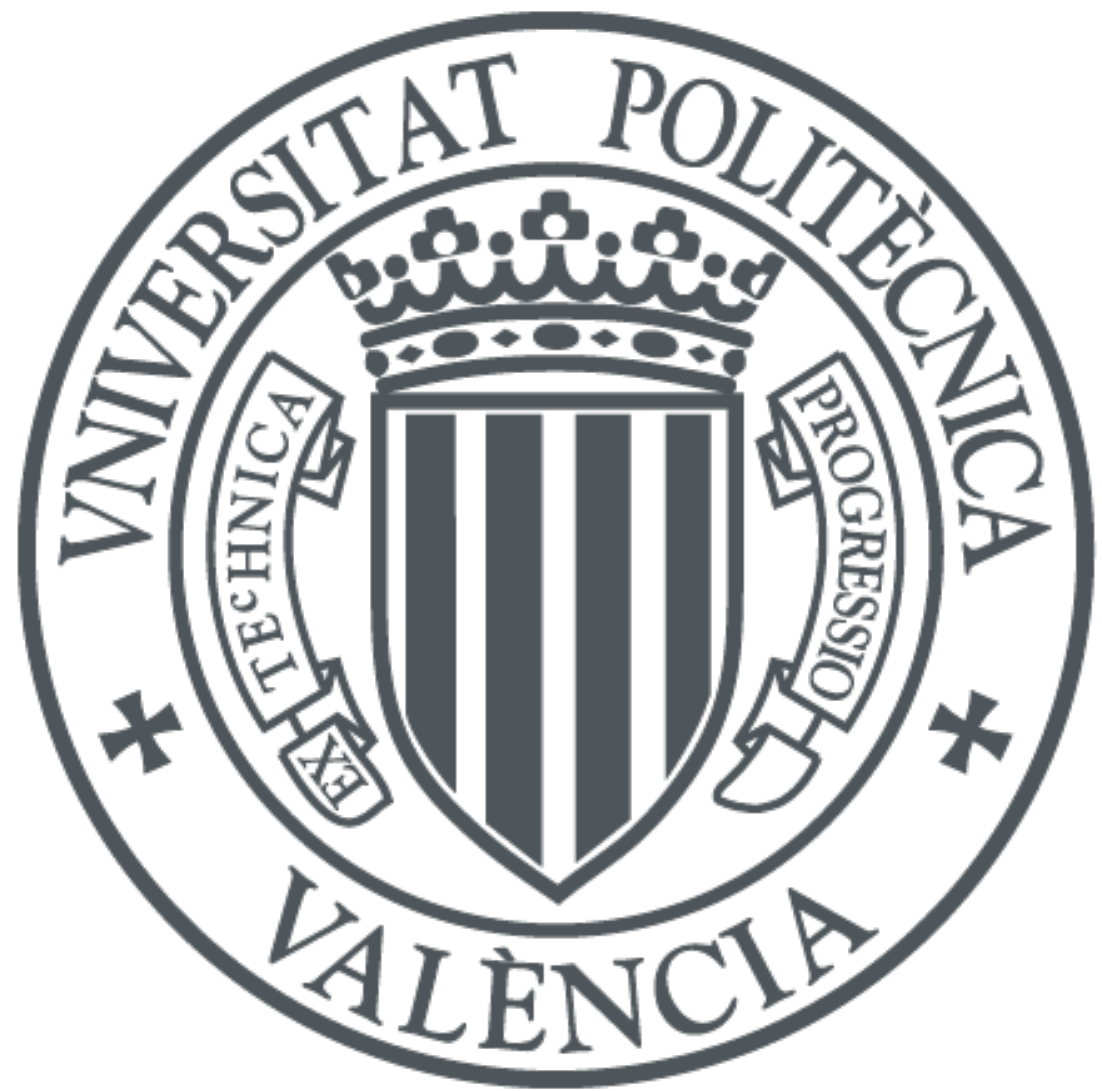

The final publication is available at

https://doi.org/10.1080/09637486.2018.1542665

Copyright Taylor \& Francis

Additional Information 


\section{Fat Digestibility in Meat Products: Influence of Food Structure and}

\section{Gastrointestinal Conditions}

3

4 Andrea Asensio-Grau ${ }^{\mathrm{a}^{*}}$, Joaquim Calvo-Lerma ${ }^{\mathrm{ab}}$, Ana Heredia ${ }^{\mathrm{a}}$ and Ana

5 Andrés $^{\mathrm{a}}$

6

7 a Instituto de Ingeniería de Alimentos para el Desarrollo, Universitat Politècnica de

8 València, Valencia, Spain

9 b Instituto de Investigación Sanitaria La Fe. Hospital Universitario La Fe, Valencia,

10 Spain

$11 *$ corresponding author: anasgr@upv.es

12

13

14

15

16

17

18

19

20

21

22

23

24

25

26 

Gastrointestinal Conditions

Digestibility of macronutrients depends on the food matrix structure as well as on gastrointestinal conditions, especially in patients with exocrine pancreatic insufficiency. In this situation, an oral enzyme supplementation that promotes nutrient hydrolysis is needed. In this context, in the present study, a static in vitro digestion model was used to assess the lipid digestibility of different meat products (processed and fresh), different intestinal conditions of $\mathrm{pH}$ (6 or 7), bile concentration ( 1 or $10 \mathrm{mM}$ ), and doses of the enzyme supplement (1000 to 4000 lipase units/g fat). Results showed that processed (unstructured) meats had better matrix degradation during digestion and reached higher values of lipolysis extents (total free fatty acids/ $g$ fat) than the natural meat matrices with a statistically significant association $(\mathrm{p}<0.001)$. Regarding the intestinal medium, $\mathrm{pH}$ of 7 and bile concentration of $10 \mathrm{mM}$ contribute to higher matrix degradation, and thus, to a higher lipolysis $(\mathrm{p}<0.001)$.

Keywords: in vitro digestion, lipolysis, nutrition, pancreatic insufficiency, food matrix

\section{Introduction}

Nowadays meat products are overconsumed in the western societies, both in young and adult populations, and the consumption exceeds the recommended daily intake (Huybrechts et al, 2010, Moreira et al, 2010, Pérez-Rodrigo et al. 2015, Roccaldo et al. 2014). Processed meats are the preferred choice over the fresh varieties because processed meat products are cheaper and easier to prepare. Moreover, the fast-food type restaurants, which offer mainly the varieties of meat that are already prepared and processed, are a frequent meal choice (Bhutani, Schoeller et al. 2018, Close et al. 2016, French et al. 2001).

Meat is an important source of protein and vitamins and its composition also contains fat and water (Pereira and Vicente 2013). Different meats and cuts are composed of distinctive types of muscle fibres and they contain varying amounts of connective tissues. This implies that the quality and structure of them are very diverse (Greenfield et al. 2009). In addition, the processing method of meat, as well as 
including the cooking technique, may also affect the final structure resulting in a wide variety of food matrices in this food group (Bax et al.2012, Luo et al. 2018). Concerning the fat fraction and quality of the meat, they depend on the area of the meat portion as well as the origin of the animal.

While several studies assessing proteolysis in meat products have been published in the recent years, scarce literature is available regarding the study of lipolysis. Given the direct effect of dietary fat intake on the development of diet-based diseases (de Souza et al. 2015), it is important to unveil the digestion fate of this nutrient when it comes from a food choice as popular as meat.

Processed meats normally have a higher fat content than non-processed varieties, as they are made of the animal parts that are less consumed, have less sensory quality and a lower consumer acceptance. However, apart from the fat content, the structure also could influence digestibility of this nutrient. Concretely, in natural structure of meat, fat molecules are embedded in muscle fibres while processed meats have an unstructured mixture of fat, protein and water, and in some cases, carbohydrates are also added (Guo et al. 2017). Therefore, in order to address the study of lipid digestibility in meat, the influence of the meat structure should be taken into account.

Lipid digestion is a complex process, which takes place in the duodenal region of the small intestine, which implies a previous micellization in order to provide the enzyme access allowing lipid hydrolysis. During this process, the intestinal $\mathrm{pH}$ and the presence of bile salts are crucial to improve the enzymatic hydrolysis (Ryan et al. 2008, Whitcomb et al. 2010). The intestinal $\mathrm{pH}$ is directly related to the enzyme activity and efficiency. Moreover, the bile salts act as emulsifying agents leading to the micellization of fat and providing a larger surface area on the fat globule for the enzyme to adsorb. However, the alteration of these factors could compromise the lipid digestibility in some individuals who suffer from exocrine pancreatic insufficiency (EPI), mainly present in patients with Cystic Fibrosis. The obstruction of the pancreatic duct in EPI produces an insufficient secretion of pancreatic juice, which contains the digestive enzymes. Moreover, the secretion of sodium bicarbonate $\left(\mathrm{NaHCO}_{3}\right)$ is also reduced, causing a drop in the intestinal $\mathrm{pH}$ and the consequent reduction of the pancreatic enzymes activity. This situation leads to the mal-digestion and malabsorption of nutrients (Layer and Keller 2003, Naikwade et al. 2009). The treatment for EPI consists in oral administration of pancreatic enzyme supplements, containing proteases and mainly lipase (Armand et al. 2011). The current guidelines for nutritional 
management in Cystic Fibrosis recommend a dose of the enzymatic supplement of 2000 - 4000 LU/ g fat, with a very low degree of evidence (Turck et al. 2016). The modulation of both intestinal $\mathrm{pH}$ and bile salts concentration in the intestinal digestion medium are thus of upmost relevance in the process of lipolysis.

In vitro studies are a useful tool that allows studying the structural changes, the digestibility and release of food components under simulated gastrointestinal conditions. In this context, the goal of the present study was to evaluate the influence of gastrointestinal conditions associated with EPI (intestinal $\mathrm{pH}$, bile salts concentration and the dose of the enzyme supplement) as well as the effect of the food matrix on lipid digestibility in different meat products.

\section{Materials and methods}

\section{Materials}

The different meat products (hamburger (just the meat patty, 100\% minced pork meat), sausage, luncheon ham, cooked ham, cured ham, pate, chicken drum, pork loin and beef steak were obtained from a local supermarket in Valencia (Spain).

For the preparation of the simulated digestive fluids (Table 1) the following chemicals were needed: human $\alpha$ - amylase (1000 - $3000 \mathrm{U} / \mathrm{mg}$ protein) (CAS: 900119-8), pepsin from porcine gastric mucosa ( $\geq 2500 \mathrm{U} / \mathrm{g}$ protein) (CAS: 9001-75-6), bovine bile extract (CAS: 8008-63-7), $\mathrm{KCl}, \mathrm{KH}_{2} \mathrm{PO}_{4}, \mathrm{NaHCO}_{3}, \mathrm{NaCl}, \mathrm{MgCl}_{2}(\mathrm{H} 2 \mathrm{O})_{6}$, $\left(\mathrm{NH}_{4}\right)_{2} \mathrm{CO}_{3}$ and $\mathrm{CaCl}_{2}$, all of them from Sigma-Aldrich Chemical Company (St Louis, MO, USA). $\mathrm{NaOH}(1 \mathrm{~N})$ and $\mathrm{HCl}(1 \mathrm{~N})$, were all acquired from AppliChem Panreac. Pancreatic enzymes supplements (Kreon 10,000 lipase units (LU)) were used to simulate in vitro digestion of an individual with EPI. Each capsule contains $150 \mathrm{mg}$ of gastro-resistant microspheres containing porcine pancreatic enzyme equivalent to 10,000 lipase U., 8,000 amylase U., and 600 protease U. The specific lipase activity of the Kreon was usually measured before the experiments (Carriere et al. 2000) and the amount of supplement added to the gastric stage was adjusted always to have the corresponding LU/g fat according to the experimental design.

For the analytical determinations, Triton-X $100 \%$, as well as the analytical standard of palmitic acid, were acquired from Sigma-Aldrich. Ethanol $(96 \% \mathrm{v} / \mathrm{v}$ for analysis) was acquired from AppliChem Panreac.

\section{Sample preparation}


128 Prior to the digestion process, hamburger, chicken drum, pork loin and beef steak were 129 placed in a microwavable plate and cooked in a household microwave oven (model $130 \mathrm{GW} 72 \mathrm{~N}$, Samsung) for $4 \mathrm{~min}$ at $600 \mathrm{~W}, 2450 \mathrm{MHz}$. For the rest of the matrices 131 (luncheon ham, pate, cured ham, cooked ham and sausage) a thermic treatment was not

132 necessary because they were ready to eat. After their preparation, all samples were in 133 vitro digested by using a static system.

\section{In vitro digestion process}

136 Meat samples were placed into falcon tubes $(50 \mathrm{ml})$; the amount of samples to be 137 digested was weighted in order to have $0.35 \mathrm{~g}$ of fat in each tube. Fat, water and protein 138 content in all meat products was determined before digestion by the official methods 139 (AOAO, 2000).

140 The digestion proceeding used was based on the standardized static in vitro 141 digestion method for food published by Minekus et al. (2014) with some modifications 142 in order to allow for analysing EPI conditions. Table 1 illustrates the amounts and 143 composition of the fluids required in each of the stages of the digestion process 144 (Minekus et al. 2014). The digestion fluids were prepared daily from stock solutions, 145 salivary (SSS), gastric (SGS) and intestinal (SIS) prepared according to Minekus et al. 146 (2014). The enzymatic activity was tested before each simulation following the protocol 147 proposed by Carriere et al., (2000). The in vitro digestion process was performed as 148 follows:

149 Oral stage: Simulated salivary fluid $(5 \mathrm{ml})(\mathrm{SSF} ; \mathrm{pH} 8)$ at $37^{\circ} \mathrm{C}$, was added to 150 the meat sample in a 1:1 (w/v) ratio and properly homogenized with a kitchen blender 151 for 3 minutes (Vario Mixer, Ufesa $600 \mathrm{~W}$ ). Salivary amylase was added into SSF to reach a concentration in the saliva mixture of $75 \mathrm{U} / \mathrm{ml}$.

153 Gastric stage: After the oral stage, simulated gastric fluid (SGF; pH 3) was 154 added to each tube containing the oral bolus (1:1 v/v). Pepsin was added into the SGF to 155 reach a concentration in the gastric mixture of $2000 \mathrm{U} / \mathrm{ml}$. The $\mathrm{pH}$ of the mixtures was 156 adjusted with $\mathrm{HCl}(1 \mathrm{~N})$ to $\mathrm{pH} 2.8 \pm 0.1$ and samples were flipped from top to bottom at 15755 rpm for 2 hours using an Intell-Mixer RM-2 (Elmi Ltd, Riga, LV-1006, Latvia) and 158 incubated at $37{ }^{\circ} \mathrm{C}$ in a chamber Selecta (JP Selecta SA, Barcelona). These mixing 159 conditions provided constant mechanical energy to induce the breakdown of the food 160 matrix during digestion. The pancreatic supplement was added in the gastric stage in 161 order to simulate swallowing the pill in case of EPI situations. 
163 7) was added in a $1: 1(\mathrm{v} / \mathrm{v})$ proportion to each tube containing the gastric chime. The $\mathrm{pH}$ 164 of the mixtures was adjusted to $\mathrm{pH} 6.0 \pm 0.1$ or $7.0 \pm 0.1$, depending on the conditions 165 to be tested, with $\mathrm{NaOH}(1 \mathrm{~N})$. Samples were then being agitated from top to bottom at $16655 \mathrm{rpm}$ for another 2 hours at $37^{\circ} \mathrm{C}$. $\mathrm{pH}$ was monitored during the digestion process and 167 readjusted if necessary to keep it constant (González-Bacerio et al. 2010, Prazeres et al. 168 1994).

\section{Experimental design}

171 The experimental design for each type of product (hamburger, sausage, luncheon ham, cooked ham, cured ham, pate, chicken drum, pork loin and beef steak) consisted of two main sets of experiments. In the first, intestinal conditions were fixed at $\mathrm{pH} 6$ and bile salts concentration $1 \mathrm{mM}$, and different pancreatin supplement doses $(0,1000,2000$, 3000 and $4000 \mathrm{LU} / \mathrm{g}$ of lipid) were tested, in order to assess the influence of enzyme concentration. In the second, the dose of enzymes was fixed at $2000 \mathrm{LU} / \mathrm{g}$ of lipid, and the study variables were different combinations of intestinal $\mathrm{pH}$ and bile concentration: pH6 - $1 \mathrm{mM}, \mathrm{pH} 6-10 \mathrm{mM}, \mathrm{pH} 7-1 \mathrm{mM}$ and $\mathrm{pH} 7-10 \mathrm{mM}$, in order to analyse the impact of different intestinal scenarios on lipolysis, and matrix degradation. Of note, the combination $\mathrm{pH} 6-1 \mathrm{mM}$ would represent the most unfavourable condition in the gastrointestinal tract in EPI (Clarke 2001, Gelfond et al. 2013, Harries et al. 1979, Rovner et al. 2013, Vu et al. 2000), and the pH $7-10 \mathrm{mM}$ would approach the standard duodenal conditions of a healthy adult. All the experiments were conducted in triplicate.

\section{Analytical determinations}

Matrix Degradation Index (MDI (\%))

187 Matrix Degradation Index (MDI) was determined in all samples after in vitro digestion.

188 This parameter represents the proportion of solids that were finely dispersed in the final 189 product of digestion. The total content of a digestion tube was centrifuged ( $4000 \mathrm{x} \mathrm{g}$ for 19020 minutes, $\left.4{ }^{\circ} \mathrm{C}\right)$ and filtered by a metallic sieve (1.6 $\mathrm{mm} \times 1.6 \mathrm{~mm}$ mesh) to separate out large particles. The drained liquid was collected and used to determine the free fatty acids. The solid particles were rinsed twice with $5 \mathrm{ml}$ of appropriate juice to remove any digested material. Blotting paper was placed around the metallic sieve for 10 minutes to drain residual digestion juice. The solid meat particles were then transferred to an aluminum dish and immediately weighed. The aluminum dish was put in a forced air 
oven at $60^{\circ} \mathrm{C}$ for 48 hours and weighed again to determine the mass of large solids. The

197 MDI, corresponding to the proportion of solids passing the metallic sieve, was

198 calculated according to Lamothe et al. (2012, 2014).

199 Lipolysis extent (\%)

200 Drained juice from digested samples was diluted 100-fold with a solution made of 5.6\%

201 Triton X-100 and 6\% ethanol in water (Lamothe et al. 2012) . This solution was used to

202 solubilize the free fatty acids (FFA) and stop the lipase activity. Fatty acids release

203 during digestion was measured on the diluted samples using a free fatty acid

204 colorimetric assay kit (Roche Diagnostics, Indianapolis, IN, USA) and a

205 spectrophotometer (UV/vis, Beckman Coulter) (Lamothe et al. 2014). Palmitic acid

206 standard was used for quantitative determination of FFA. Total FFA was expressed as

$207 \mathrm{mg}$ of fatty acids released after a complete digestion per gram of initial fat present in

208 each meat product.

210 Statistical analysis

211 The variables included for the statistical analysis were the nutrient composition of

212 foods: water, protein and fat, starch; and the food matrix structure: natural food matrix

213 (protein fibres) or processed matrix (unstructured); the pancreatic enzyme supplement

214 concentration (enzyme dose); the intestinal conditions: $\mathrm{pH}$ and bile salts concentration;

215 and the matrix degradation index (MDI). The response variables were lipolysis extent

216 (total FFA) and the MDI.

217 Data were summarised using mean, standard deviation, median and $1^{\text {st }}$ and $3^{\text {rd }}$

218 quartile in the case of continuous variables and with absolute ant relative frequencies in

219 the case of categorical variables.

220 Linear mixed regression models were performed to assess the effect of the food

221 matrix structure and other factors such as matrix degradation index were included as

222 covariates. Additionally, because observations of the same food are more likely to have

223 similar lipolysis extent due to their nutritional characteristics, the linear regression

224 models were extended with the "Food" variable as random effect with random intercept

225 to correct for the non-independence of the data.

226 All the analyses were performed by software R (version 3.4.2) using packages

227 betareg (version 3.1-0), lme4 (version 1.1-14) and NMF (version 0.20.6). A p-value

228 lower than 0.05 was considered statistically significant. 


\section{Results and discussion}

\section{Effect of the food structure on matrix degradation and fat digestibility}

The degradation of the food matrix is the process by which the 3D structural conformation of a food is disrupted into smaller parts allowing for the release of the structural components, i.e. the nutrients (Table 2). It is facilitated by several mechanisms: mainly the mechanical forces produced along the gastrointestinal tract (chewing in the mouth, stomach walls agitation and small intestine peristaltic movements) and the enzymatic activity that contributes to the breakdown of nutrients conforming the matrix structure. Thus, when no enzymes were used in the in vitro digestion, significantly lower matrix degradation indexes were obtained (Figure 1) as compared to digestions conducted with pancreatic enzyme supplements. Generally, the enzymatic supplements increase of $1000 \mathrm{LU} / \mathrm{g}$ of fat led to a minor increase in the MDI. In the case of the natural matrices (protein fibres) maximum MDI were between 50 and $75 \%$, while in the unstructured matrices higher degradation extents were reached $(>75 \%)$.

In terms of fat digestibility (total release of FFA), a similar tendency as in the MDI was shown for all the assessed meat products (Figure 2). In those matrices which preserve the protein fibres structure, the total FFA increased with the concentration of the enzymatic supplement up to $3000 \mathrm{LU} / \mathrm{g}$ fat, and it slightly decreased at $4000 \mathrm{LU} / \mathrm{g}$ fat, probably due to inactivation by aggregation. It has been described that when a high concentration of enzymes is not active in the reaction medium (e.g. because there is no substrate available) aggregation and inactivation occur. Furthermore, the release of fat particles from the protein fibres complex is a progressive and slow process, so this may lead to a low concentration of substrate at the beginning of the digestion. This may be the reason of the inactivation phenomenon (López-Gallego et al. 2005). In contrast, in unstructured matrices, the release of FFA was directly proportional to the concentration of enzymes. Pate and luncheon meat reached a total FFA released close to $600 \mathrm{mg} / \mathrm{g}$ fat at enzyme dose of $4000 \mathrm{LU} / \mathrm{g}$ fat. On the other hand, hamburger and sausage reached a lipolysis extent of 500 and $300 \mathrm{mg} \mathrm{FFA} / \mathrm{g}$ fat, respectively. In any case, the highest value of lipolysis was reached at enzyme dose of $3000 \mathrm{LU} / \mathrm{g}$ fat.

The fact that MDI and total FFA released followed the same tendency was, indeed, statistically explained, finding significant associations between the type of matrix and the MDI, and between the MDI and the fat digestibility (Figure 3). The unstructured matrices allowed for higher MDI than the natural protein fibres, up to 
$30.6 \%$ more $(\mathrm{p}=0.013,95 \%$ CI $[8.148,30.612])$; and the higher MDI were associated with higher total FFA released, every $1 \%$ increase produced between 6.1 and $9.6 \mathrm{mg}$ of FFA more ( $\mathrm{p}<0.001,95 \%$ CI $[6.128,9.606])$.

These relationships are backed up by previous literature providing a physical explanation, as previously compiled by Guo et al. (2017). When fat molecules are trapped in a solid food matrix, the structure of the surrounding food matrix is the dominant factor controlling digestion. In order to make lipids available to the enzymes, the degradation of the protein food matrix has to occur. In such systems, lipolysis is thus conditioned by the rate and extent of proteolysis: as the protein structure is broken down, the lipids are released from the matrix, and lipases can start hydrolysis (Dickinson 2012). An example of this type of system was described by Dickinson (2012), in which protein gels containing lipids were formulated with different amounts of protein and forming different microstructures (hard and soft gels). The soft gel presented an in vitro digestion behaviour similar to a liquid whey protein emulsion, but the hard gel showed slower lipolysis rates and extents, as the gel structure was degraded along digestion and allowed for fat droplets release from the matrix (Guo et al. 2017, Guo et al. 2016).

Another example supporting our findings is the study of fat digestibility in chewed almonds versus their isolated fat molecules, which lipolysis extents were 22 and $69 \%$ after one hour of in vitro digestion (Grundy et al. 2017). The study pointed at the fact that cells remained largely intact after mastication and concluded that lipid bioaccessibility in almonds was dependent on the structure and the cell walls surrounding the oil droplets.

Finally, the role of the food structure in protein-lipid matrices has been also assessed in two types of cheese (Fang et al. 2016). Cheddar cheese had larger fat globules that made the structure less hard and more easily degraded. On the other hand, the mozzarella had a denser fibrous protein matrix. In terms of digestibility, it was higher in cheddar as fat globules were rapidly released and accessible to the enzymes, while in mozzarella the fibrous structure prevented fat release and thus led to a lower lipolysis extent.

In the present study, natural protein fibres matrix represents a robust structure in which lipids are contained, and the unstructured matrices suppose a softer system in which lipid and protein are not bonded or linked to each other. This structural fact 
explains why the unstructured matrices had more MDI and consecutively a higher amount of FFA release.

Apart from the food structure, the conditions of the digestive fluid and the intestinal environment may also affect the behaviour of food digestion. These are explored and explained in the coming section.

\section{Effect of the intestinal conditions on matrix degradation and fat digestibility}

304

305

306

307

308

309

310

311

312

313

In all the assessed intestinal conditions, the unstructured matrix meat products had higher MDI than the structured, values ranging from 69 to $78.6 \%$ and 42 to $70 \%$, respectively (Table 3). The intestinal $\mathrm{pH}$ had a significant effect on the matrix degradation index, as in all the assessed meat products it allowed for an increase between 5 and $15 \%$ ( $\mathrm{p}<0.01$ ). However, when comparing the effect of the bile salts concentration at intestinal $\mathrm{pH} 6$ or at $\mathrm{pH} 7$, this showed a non-significant increase in the matrix degradation index. Pate was an exception, in which MDI increased 7\% at the 10 $\mathrm{mM}$ concentration, both in $\mathrm{pH} 6$ and 7 . In contrast, the role of bile was not significant in proteolysis, but it was important on lipolysis due to the bile emulsify the lipids allowing a higher surface area available for the lipases action.

Overall, in terms of fat digestibility, the release of total FFA was significantly higher at pH 7 ( p <0.001, 95\% CI [53.5, 168.9]) and at bile salts concentration of 10 $\mathrm{mM}$ (p <0.001, 95\% CI [90.2, 205.6]) (Figure 4). The 95\% CI represent the extent to which the $\mathrm{pH} 7$ and bile $10 \mathrm{mM}$ conditions produce an increase in the total FFA. This is in accordance to previous studies conducted by our group (Asensio-Grau et al. 2018, Peinado et al. 2018)

Focusing on the results when considering the food products and their type of matrix, more concrete patterns could be depicted (Table 4). Digestions conducted at intestinal $\mathrm{pH} 7$, revealed that in the protein fibre matrices the higher concentration of bile salts led to a significant increase in total FFA release of up to $300 \mathrm{mg} / \mathrm{g}$ fat, while this effect of bile concentration showed a lower increase in the unstructured matrices (50 mg/ g fat, except for luncheon ham whose increase was higher). In contrast, the unstructured matrices were more influenced by the $10 \mathrm{mM}$ bile salts concentration in the intestinal pH 6 scenario, which produced an increase of around $150 \mathrm{mg}$ of FFA released per gram of fat as compared to the use of $1 \mathrm{mM}$ bile. At this last $\mathrm{pH} 6$ and $1 \mathrm{mM}$ combination, the natural protein fibres matrices did not show a common pattern. Although the $10 \mathrm{mM}$ concentration allowed for a higher amount of FFA release in all 
the meat products, the increase was up to different extents: the highest was in beef steak (400 mg/g fat) and the lowest in chicken drum (which showed no increase).

Thus, at intestinal $\mathrm{pH} 7$ bile concentration plays a crucial role in natural matrices while it is not relevant in the unstructured matrices; and at $\mathrm{pH} 6$, the higher bile concentration improves FFA release in unstructured matrices but shows a rather random effect in the natural ones. On the one hand, bile salts are bio-surfactant compounds that play a crucial role in lipid digestion. They adsorb onto lipid droplets and remove proteins, emulsifiers and free fatty acids (lipolysis products). This mechanism facilitates lipases' access and action (Maldonado-Valderrama et al. 2011, Harries et al. 1979). On the other hand, the intestinal $\mathrm{pH}$ environment determines enzymatic activity and also influences the isoelectric point of the protein that may be present at the lipid droplet interface causing isoelectric effects. This fact may change the protein to a cationic form allowing the bind to the anionic bile salts. Consequently, different meat matrices result in different systems during digestion in which proteins can interact with the bile salts either promoting or inhibiting the activity of pancreatic lipase (Bauer et al. 2005, Lowe 2002).

To sum up, unstructured matrices led to higher MDI than the structured ones; higher MDI led to higher lipolysis extents (\%); and the intestinal pH 7 and the $10 \mathrm{mM}$ bile salts concentration allowed for higher lipolysis extents. These associations, explained by means of linear regression models, are summarised in Table 5.

Overall, a main limitation has been identified when aiming at discussing the results. There are no studies conducted in meat products assessing lipolysis, and in contrast, all of them focus on proteolysis. Nonetheless, two papers related to this topic were found: one study assessing lipid digestibility of pork patties depending on the thermal treatment (Hur et al. 2014), and another compiling knowledge about factors affecting lipolysis in fish (Olsen and Ring $\varnothing$ 1997). This scarcity has prevented the comparison of the results to previous literature. This is a point of special relevance: characterising the role of lipid digestion in meat products is of upmost necessity, as recently the consumption of red meat products and cold meat derivatives has been classified by the World Health Organisation as a major determinant in the development of cancer (McGuire 2016). In addition, processed meat products have been traditionally characterised by a high content of fat, mainly composed of saturated fatty acids. This type of fat is unequivocally associated to the development of nutrition related conditions such as high blood pressure and diseases like obesity (Chen et al. 2016). 


\section{Conclusion}

367 In conclusion, fat digestibility in a wide range of meat products has been screened and characterised for the first time regarding their composition, structure and intestinal digestion conditions. The results reveal that lipolysis extent is dependent on the food matrix degradation, and that unstructured processed meats allow for higher amount of free fatty acids release than the natural protein fibrous matrices. In addition to the food structure, the bile salts concentration in the digestion and the $\mathrm{pH}$ in the intestinal digestion medium, contribute significantly to the fate of lipid digestion in meat products.

\section{Acknowledgements}

Authors of this paper acknowledge the European Union and the Horizon 2020 Research and Innovation Framework Programme (PHC-26-2014 call Self-management of health and disease: citizen engagement and mHealth) for fully funding this research in the context of MyCyFAPP Project, under grant agreement number 643806. The authors also thank the Conselleria de Educació i Investigació de la Generalitat Valenciana for the PhD scholarship given to Andrea Asensio Grau. Finally, we thank Antonio Martínez Cañada, from the Data Science and Biostatistics Unit of Instituto de Investigación Sanitaria La Fe, and Arash Javanidejad for the English corrections.

Declaration of interest: The authors report no conflicts of interest. The authors alone are responsible for the content and writing of the paper.

\section{References}

AOAC. 2000. Official methods of analysis of AOAC International. (17th ed.). Gaithersberg, Maryland: Association of Official Chemists.

Armand, Fieker, A. P., \& Philpott, J. (2011). Enzyme replacement therapy for pancreatic insufficiency: present and future. Clin. Exp. Gastroenteroll. 4: 55. https://doi.org/10.2147/CEG.S17634

Asensio-grau A, Peinado I, Heredia A, Andrés A. 2018. Effect of cooking methods and intestinal conditions on lipolysis, proteolysis and xanthophylls bioaccessibility of eggs. J. Funct Foods.46: 579-586. https://doi.org/10.1016/j.jff.2018.05.025

Bauer E, Jakob S, Mosenthin R. 2005. Principles of physiology of lipid digestion. 
Asian-Australas J. Anim. Sci. 18: 282-295.

400

Bax ML, Aubry L, Ferreira C, Daudin JD, Gatellier P, Rémond D, Santé-Lhoutellier V. 2012. Cooking temperature is a key determinant of in vitro meat protein digestion rate: Investigation of underlying mechanisms. J. Agr. Food Chem. 60: 2569-2576. https://doi.org/10.1021/jf205280y

Bhutani S, Schoeller DA, Walsh MC, McWilliams C. 2018. Frequency of Eating Out at Both Fast-Food and Sit-Down Restaurants Was Associated With High Body Mass Index in Non-Large Metropolitan Communities in Midwest. Am. J. Health Pr. 32(1), 75-83. https://doi.org/10.1177/0890117116660772

Carriere F, Renou C, Lopez V, De Caro J, Ferrato F, Lengsfeld H, Verger, R. 2000. The specific activities of human digestive lipases measured from the in vivo and in vitro lipolysis of test meals. Gastroenterology. 119: 949-960. https://doi.org/10.1053/gast.2000.18140

Chen M, Li Y, Sun Q, Pan A, Manson JE, Rexrode KM, Hu FB. 2016. Dairy fat and risk of cardiovascular disease in 3 cohorts of US adults. Am. Journal of Clin Nutr. 104. 1209-1217. https://doi.org/10.3945/ajcn.116.134460

Clarke LL, Stien X, Walker NM. 2001. Intestinal bicarbonate secretion in cystic fibrosis mice. JOP : J. Pancreas. 2: 263-267.
Close MA, Lytle LA, Viera AJ. 2016. Is frequency of fast food and sit-down restaurant eating occasions differentially associated with less healthful eating habits? Prev. Med. 4, 574-577. https://doi.org/10.1016/j.pmedr.2016.10.011

De Souza RJ, Mente A, Maroleanu A, Cozma AI, Ha V, Kishibe T, Anand SS. 2015. Intake of saturated and trans unsaturated fatty acids and risk of all cause mortality, cardiovascular disease, and type 2 diabetes: systematic review and meta-analysis of observational studies. Bmj, h3978. https://doi.org/10.1136/bmj.h3978

Dickinson E. 2012. Emulsion gels: The structuring of soft solids with protein-stabilized oil droplets. Food Hydrocolloids. 28: 224-241. https://doi.org/10.1016/j.foodhyd.2011.12.017

Fang X, Rioux LE, Labrie S, Turgeon SL. 2016. Disintegration and nutrients release from cheese with different textural properties during in vitro digestion. Food Research International, 88, 276-283. https://doi.org/10.1016/j.foodres.2016.04.008 restaurant use among adolescents: Associations with nutrient intake, food choices and behavioral and psychosocial variables. Int. J. Obes. 25: 1823-1833. 
https://doi.org/10.1038/sj.ijo.0801820

Gelfond D, Ma C, Semler J, Borowitz D. 2013. Intestinal ph and gastrointestinal transit profiles in cystic fibrosis patients measured by wireless motility capsule. Dig. Dis. Sci. 58: 2275-2281. https://doi.org/10.1007/s10620-012-2209-1

González-Bacerio J, Hernández JR, Martínez ADM. 2010. Las lipasas: enzimas con potencial para el desarrollo de biocatalizadores inmovilizados por adsorción interfacial. Rev. Colomb. Bio. 12: 124-140.

Greenfield H, Arcot J, Barnes JA, Cunningham J, Adorno P, Stobaus T, Muller WJ. 2009. Nutrient composition of Australian retail pork cuts 2005/2006. Food Chem. 117: 721-730. https://doi.org/10.1016/j.foodchem.2009.04.048

Grundy MML, Quint J, Rieder A, Ballance S, Dreiss CA, Cross KL, Wilde PJ. 2017. The impact of oat structure and $\beta$-glucan on in vitro lipid digestion. J. Funct. Foods. 38, 378-388. https://doi.org/10.1016/j.jff.2017.09.011

Guo Q, Ye A, Bellissimo N, Singh H, Rousseau D. 2017. Modulating fat digestion through food structure design. Prog. Lipid Res. 68: 109-118. https://doi.org/10.1016/j.plipres.2017.10.001

Guo Q, Ye A, Lad M, Dalgleish D, Singh H. 2016. Impact of colloidal structure of gastric digesta on in-vitro intestinal digestion of whey protein emulsion gels. Food Hydrocolloids. 54: 255-265. https://doi.org/10.1016/j.foodhyd.2015.10.006

Hur SJ, Lee SY, Moon SS, Lee SJ. 2014. In vitro effects of cooking methods on digestibility of lipids and formation of cholesterol oxidation products in pork. Korean J. Food Sci. An. 34: 280-286.

Huybrechts I, Maes L, Vereecken C, De Keyzer W, De Bacquer D, De Backer G, De Henauw S. 2010. High dietary supplement intakes among Flemish preschoolers. Appetite, 54(2), 340-345. https://doi.org/10.1016/j.appet.2009.12.012

Lamothe S, Azimy N, Bazinet L. 2014. Function Interaction of green tea polyphenols with dairy matrices in a simulated gastrointestinal environment. Food Func. 5:2621-2631. https://doi.org/10.1039/C4FO00203B

Lamothe S, Corbeil MM, Turgeon SL, Britten M. 2012. Influence of cheese matrix on lipid digestion in a simulated gastro-intestinal environment. Food Func. 3: 724-31. https://doi.org/10.1039/c2fo10256k

Layer P, Keller J. 2003. Lipase Supplementation Therapy: Standards, Alternatives, and Perspectives. Pancreas. 26: 1-7. https://doi.org/10.1097/00006676-20030100000001 
López-Gallego F, Betancor L, Hidalgo A, Alonso N, Fernández-Lafuente R, Guisán JM. 2005. Co-aggregation of enzymes and polyethyleneimine: A simple method to prepare stable and immobilized derivatives of glutaryl acylase. Biomacromolecules. 6: 1839-1842. https://doi.org/10.1021/bm050088e

Lowe ME. 2002. The triglyceride lipases of the pancreas. J. Lipid Res. 43: 2007-2016.

Luo J, Taylor C, Nebl T, Ng K, Bennett LE. 2018. Effects of macro-nutrient, micronutrient composition and cooking conditions on in vitro digestibility of meat and aquatic dietary proteins. Food Chem. 254: 292-301. https://doi.org/10.1016/j.foodchem.2018.01.164

Maldonado-Valderrama J, Wilde P, MacIerzanka A, MacKie A. 2011. The role of bile salts in digestion. Adv. Colloid Interface Sci. 165: 36-46. https://doi.org/10.1016/j.cis.2010.12.002

Minekus M, Alminger M, Alvito P, Ballance S, Bohn T, Bourlieu C, Brodkorb A. 2014. A standardised static in vitro digestion method suitable for food-an international consensus. Food Func. 5: 1113-1124. https://doi.org/10.1039/c3fo60702j

Moreira P, Santos S, Padrão P, Cordeiro T, Bessa M, Valente H, Moreira A. 2010. Food patterns according to Sociodemographics, physical activity, sleeping and obesity in Portuguese children. Int. J. Environ. Res. 7: 1121-1138. https://doi.org/10.3390/ijerph7031121

Naikwade SR, Meshram RN, Bajaj AN. 2009. Preparation and In Vivo Efficacy Study of Pancreatin Microparticles as an Enzyme Replacement Therapy for Pancreatitis. Drug Dev. Ind. Pharm. 35: 417-432. https://doi.org/10.1080/03639040802422104 Harries JT, Muller DP, McCollum JP, Lipson A, Roma E, Norman AP. 1979. Intestinal bile salts in cystic fibrosis: studies in the patient and experimental animal. Arch. Dis. Child. 54: 19-24.

Olsen RE and Ringø E. 1997. Lipid digestibility in fish: a review. Recent Res. Dev. Lipid Res.1:199-265.

Peinado I, Larrea V, Heredia A, Andrés A. 2018. Lipolysis kinetics of milk-fat catalyzed by an enzymatic supplement under simulated gastrointestinal conditions. Food Biosci. 23: 1-8. https://doi.org/10.1016/j.fbio.2018.02.011

Pereira PM. de CC, Vicente A. F. dos R. B. 2013. Meat nutritional composition and nutritive role in the human diet. Meat Sci. 93: 586-592. https://doi.org/10.1016/j.meatsci.2012.09.018

Pérez-Rodrigo C, Gil Á, González-Gross M, Ortega RM., Serra-Majem L, Varela- 
Moreiras G, Aranceta-Bartrina J. 2015. Clustering of dietary patterns, lifestyles, and overweight among Spanish children and adolescents in the ANIBES study. Nutrients, 8(1), 1-17. https://doi.org/10.3390/nu8010011

Prazeres DMF, Garcia FAP, Cabral MS. 1994. Bioprocess Engineering Continuous lipolysis in a reversed micellar membrane bioreactor, 10, 21-27.

Roccaldo R, Censi L, D’Addezio L, Toti E, Martone D, D'Addesa D, Cernigliaro A. 2014. Adherence to the Mediterranean diet in Italian school children (The ZOOM8 Study). Int- J. Food Sci. Nutr. 65: 621-628. https://doi.org/10.3109/09637486.2013.873887

Rovner AJ, Schall JI, Mondick JT, Zhuang H, Mascarenhas MR. 2013. Delayed small bowel transit in children with cystic fibrosis and pancreatic insufficiency. J. Pediatr. Gastroenterol. Nutr. 57(1), 81-84. https://doi.org/10.1097/MPG.0b013e318290d112

Ryan L, O’Connell O, O’Sullivan L, Aherne SA, O’Brien NM. 2008. Micellarisation of Carotenoids from Raw and Cooked Vegetables. Plant Food Hum. Nutr. 63: 127133. https://doi.org/10.1007/s11130-008-0081-0 M. 2016. ESPEN-ESPGHAN-ECFS guidelines on nutrition care for infants , children, and adults with cystic fi brosis. Clin. Nutr. 35: 557-577. https://doi.org/10.1016/j.clnu.2016.03.004

Vu MK, Vecht J, Eddes EH, Biemond I, Lamers CB, Masclee AA. 2000.

Whitcomb DC, Lehman GA, Vasileva G, Malecka-Panas E, Gubergrits N, Shen Y, Caras S. 2010. Pancrelipase delayed-release capsules (CREON) for exocrine pancreatic insufficiency due to chronic pancreatitis or pancreatic surgery: A double-blind randomized trial. Am. J. Gastroenterol. 105: 2276-2286. https://doi.org/10.1038/ajg.2010.201 
Table 1. Composition of simulated digestion fluids.

\begin{tabular}{lccc}
\hline Constituent & $\begin{array}{c}\text { SSF } \\
\mathrm{mmol} / \mathrm{L}\end{array}$ & $\begin{array}{c}\text { SGF } \\
\mathrm{mmol} / \mathrm{L}\end{array}$ & $\begin{array}{c}\text { SIF } \\
\mathrm{mmol} / \mathrm{L}\end{array}$ \\
\hline $\mathrm{KCl}$ & 15.1 & 6.9 & 6.8 \\
$\mathrm{KH}_{2} \mathrm{PO}_{4}$ & 3.7 & 0.9 & 0.8 \\
$\mathrm{NaHCO}_{3}$ & 13.6 & 25 & 85 \\
$\mathrm{NaCl}$ & - & 47.2 & 38.4 \\
$\mathrm{MgCl}_{2}\left(\mathrm{H}_{2} \mathrm{O}\right)_{6}$ & 0.15 & 0.1 & 0.33 \\
$\left(\mathrm{NH}_{4}\right)_{2} \mathrm{CO}_{3}$ & 0.06 & 0.5 & - \\
$\mathrm{CaCl}_{2}$ & 1.5 & 0.15 & 0.6
\end{tabular}

535

536

537

538

539

540

541

542

543

544

545

546

547

548

549

550

551

552

553

554

555

556

557

The addition of pepsin, $\mathrm{Ca}^{2+}$ solution and water will result in the correct electrolyte concentration in the final digestion mixture.

SSF: Simulated Salival Fluid; SGF: Simulated Gastric Fluid; SIF:

Simulated Intestinal Fluid. 
558 Table 2. Characterization of water, fat and protein content in the different meat matrices 559 expressed as $\mathrm{g} / \mathrm{g}$ of product.

\begin{tabular}{lccc}
\hline & $\begin{array}{c}\text { Water content } \\
(\text { g/ g product })\end{array}$ & $\begin{array}{c}\text { Fat content } \\
(\text { g/ g product })\end{array}$ & $\begin{array}{c}\text { Protein content } \\
(\text { g/ g product })\end{array}$ \\
\hline Hamburger & $0.51 \pm 0.03$ & $0.24 \pm 0.04$ & $0.21 \pm 0.02$ \\
Sausage & $0.683 \pm 0.002$ & $0.107 \pm 0.003$ & $0.18 \pm 0.02$ \\
Luncheon ham & $0.653 \pm 0.002$ & $0.120 \pm 0.006$ & $0.11 \pm 0.003$ \\
Pate & $0.606 \pm 0.004$ & $0.30 \pm 0.09$ & $0.090 \pm 0.002$ \\
Cured ham & $0.529 \pm 0.03$ & $0.1 \pm 0.02$ & $0.32 \pm 0.05$ \\
Cooked ham & $0.756 \pm 0.004$ & $0.025 \pm 0.03$ & $0.199 \pm 0.006$ \\
Chicken drum & $0.649 \pm 0.012$ & $0.12 \pm 0.03$ & $0.201 \pm 0.004$ \\
Pork loin & $0.543 \pm 0.026$ & $0.135 \pm 0.06$ & $0.29 \pm 0.04$ \\
Beef steak & $0.56 \pm 0.014$ & $0.10 \pm 0.03$ & $0.30 \pm 0.03$ \\
\hline
\end{tabular}

560

561

562

563

564

565

566

567

568

569

570

571

572

573

574

575

576

577

578

579 
580 Table 3. Matrix Degradation Index (\%) obtained for the different meat matrices 581 (hamburger, sausage, luncheon ham, pate, cured ham, cooked ham, chicken drum, pork 582 loin and beef steak) after the in vitro digestion process using a fixed enzyme dose (2000 $583 \mathrm{LU} / \mathrm{g}$ fat) and different duodenal conditions of $\mathrm{pH}$ and Bile concentration.

\begin{tabular}{|c|c|c|c|c|}
\hline & pH 6 - 1 mM & pH 6-10 mM & pH $7-1 \mathrm{mM}$ & pH 7 - 10 79.9 \\
\hline \multicolumn{5}{|l|}{ MDI (\%) } \\
\hline Hamburger & $69 \pm 2$ & $69.06 \pm 1.12$ & $83 \pm 4$ & $82.1 \pm 0.9$ \\
\hline Sausage & $82 \pm 6$ & $79 \pm 3$ & $94 \pm 2$ & $96.6 \pm 1.2$ \\
\hline Luncheon ham & $86 \pm 3$ & $87.8 \pm 0.5$ & $90.38 \pm 0.13$ & $90.2 \pm 1.4$ \\
\hline Pate & $78.6 \pm 0.6$ & $85.13 \pm 1.14$ & $81.2 \pm 0.2$ & $88.957 \pm 1.014$ \\
\hline Cured ham & $70 \pm 5$ & $73.6 \pm 0.2$ & $67 \pm 5$ & $78 \pm 6$ \\
\hline Cooked ham & $55.7 \pm 0.3$ & $55.13 \pm 0.13$ & $59.1 \pm 1.2$ & $63.3 \pm 0.6$ \\
\hline Chicken drum & $63.57 \pm 1.06$ & $66 \pm 3$ & $69 \pm 4$ & $74 \pm 2$ \\
\hline Pork loin & $52 \pm 9$ & $52 \pm 6$ & $68 \pm 4$ & $68.73 \pm 0.04$ \\
\hline Beef steak & $42 \pm 2$ & $45 \pm 3$ & $51 \pm 3$ & $56 \pm 2$ \\
\hline
\end{tabular}


586 Table 4. Total FFA (mg/g fat) obtained for the different meat matrices (hamburger, 587 sausage, luncheon ham, pate, cured ham, cooked ham, chicken drum, pork loin and beef 588 steak) after the in vitro digestion process using a fixed enzyme dose (2000 LU/ $\mathrm{g}$ fat) 589 and different duodenal conditions of $\mathrm{pH}$ and Bile concentration.

\begin{tabular}{|c|c|c|c|c|}
\hline & pH 6 - 1 mM & pH $6-10 \mathrm{mM}$ & pH $7-1$ mM & pH 7 - 10 -79 \\
\hline \multicolumn{5}{|c|}{ Total FFA (mg/g fat) } \\
\hline Hamburger & $253 \pm 13$ & $376 \pm 58$ & $501 \pm 149$ & $554 \pm 115$ \\
\hline Sausage & $525 \pm 22$ & $667 \pm 26$ & $415 \pm 44$ & $490 \pm 67$ \\
\hline Luncheon ham & $498 \pm 18$ & $619 \pm 3$ & $705 \pm 1$ & $902 \pm 77$ \\
\hline Pate & $613 \pm 153$ & $710 \pm 219$ & $680 \pm 41$ & $700 \pm 147$ \\
\hline Cured ham & $344 \pm 80$ & $467 \pm 66$ & $409 \pm 85$ & $600 \pm 3$ \\
\hline Cooked ham & $298 \pm 29$ & $365 \pm 162$ & $416 \pm 131$ & $600 \pm 177$ \\
\hline Chicken drum & $248 \pm 8$ & $249 \pm 6$ & $142 \pm 109$ & $408 \pm 142$ \\
\hline Pork loin & $226 \pm 8$ & $614 \pm 67$ & $556 \pm 104$ & $653 \pm 29$ \\
\hline Beef steak & $298 \pm 4$ & $783 \pm 10$ & $675 \pm 199$ & $860 \pm 272$ \\
\hline
\end{tabular}


592 Table 5. Linear mixed regression models explaining the association between the study 593 variables

\begin{tabular}{|c|c|c|c|c|c|}
\hline \multicolumn{2}{|l|}{ Explained effect } & Estimate & $\begin{array}{l}\text { Standard } \\
\text { error }\end{array}$ & $\begin{array}{l}95 \% \text { Confidence } \\
\text { interval (CI) }\end{array}$ & p-value \\
\hline \multicolumn{2}{|c|}{$\begin{array}{l}\text { Effect of the matrix structure } \\
\text { (unstructured vs. structured) on MDI (\%) }\end{array}$} & 19.38 & 5.818 & {$[8.148,30.612]$} & 0.013 \\
\hline \multicolumn{2}{|c|}{$\begin{array}{l}\text { Effect of the MDI (\%) on lipolysis extent } \\
(\%)\end{array}$} & 8.144 & 0.856 & {$[6.128,9.606]$} & $<0.001$ \\
\hline Effect of the & Intestinal pH (7 vs. 6) & 111.19 & 29.47 & {$[53.5,168.9]$} & $<0.001$ \\
\hline intestinal & Bile salts & & & & \\
\hline $\begin{array}{l}\text { conditions on } \\
\text { lipolysis extent }\end{array}$ & $\begin{array}{l}\text { concentration (10 vs. } \\
1 \mathrm{mM})\end{array}$ & 147.9 & 29.48 & {$[90.2,205.6]$} & $<0.001$ \\
\hline$(\%)$ & & & & & \\
\hline
\end{tabular}

594 


\section{FIGURE LEGENDS}

597 Figure 1. Matrix degradation index (MDI, \%) of the meat products after in vitro 598 digestion with five pancreatic enzyme supplements concentrations (enzyme dose, LU/g 599 fat), classified according to the food matrix structure.

600

601 Figure 2. Lipolysis extent (total FFA, mg/g fat) of the meat products after in vitro

602 digestion with five pancreatic enzyme supplements concentrations (enzyme dose, LU/g

603 fat), classified according to the food matrix structure.

604

605 Figure 3. Linear mixed regression model plot. (A) Effect of the food matrix (natural or 606 processed) on matrix degradation index (MDI): processed matrices have significantly 607 higher MDI ( $\mathrm{p}=0.013$, 95\% CI [8.148, 30.612]). (B) Effect of the MDI on the total 608 FFA released: the higher the MDI, the higher the total FFA released ( $\mathrm{p}<0.001,95 \%$ CI $609[6.128,9.606])$.

610

611 Figure 4. Linear mixed regression model plot. (A) Effect of the intestinal pH (6 or 7) on 612 total FFA: pH 7 allows for significantly higher amount of FFA released ( $\mathrm{p}<0.001,95 \%$ 613 CI [53.466, 168.923]). (B) Effect of the bile salts concentration on the total FFA 614 released: $10 \mathrm{mM}$ concentration allows for significantly higher amount of FFA released $615(\mathrm{p}<0.001,95 \%$ CI $[90.188,205.645])$. 